\title{
Effect of Dietary Salt (Sodium Chloride) Supplementation on Growth, Survival and Feed Utilization of Oreochromis shiranus (Trewavas, 1941)
}

\section{Mzengereza $\mathrm{K}^{1 *}$ and Kang'ombe $\mathrm{J}^{2}$}

${ }^{1}$ Department of Fisheries Science, Mzuzu University, Private Bag 201, Mzuzu 2, Malawi

${ }^{2}$ Department of Aquaculture and Fisheries Science, Lilongwe University of Agriculture and Natural Resources, Bunda College, P.O. Box 219, Lilongwe, Malawi

\begin{abstract}
A study was conducted to determine growth response, survival and feed utilization efficiency of Oreochromis shiranus. Fingerings of $12.32 \pm 0.34 \mathrm{~g}$ were fed diets containing different levels of sodium chloride. (Diet $1=0 \%$, die $2=1 \%$, diet $3=1.5 \%$ and diet $4=2 \%$ ). Treatments were replicated three times and 25 fish were stocked in each of the $100 \mathrm{~L}$ grass tanks. Fish were fed $5 \%$ body weight twice a day. Weight measurements were recorded fortnightly. Fish fed diet 3 and diet 1 had final a weight gain $(6.45 \mathrm{~g})$ and $(5.25 \mathrm{~g})$ respectively, higher than other diets. In diet 3 fish grew from $12.24 \mathrm{~g}$ to $18.69 \mathrm{~g}$ and in diet 2 fish grew from $12.34 \mathrm{~g}$ to $17.19 \mathrm{~g}$ on average. Feed Conversion ratio (FCR) was best in diet 2 (1.51) and diet 3 (1.44), highest was in diet 4 with FCR of 1.87. Diet 1 had an average weight gain of $3.86 \mathrm{~g}$ which was statistically not $(P>0.05)$ different from that of diet $4 . \%$ Survival was higher in diet $1=0 \% \mathrm{NaCl}$ level $(97.7 \%)$ and lowest in diet $2(94.8 \%)$. The study indicates that salt can be incorporated in fish diets enhance growth, but can be used up to a limit beyond which growth is compromised.
\end{abstract}

Keywords: Oreachromis shiranus; Dietary salt; Feed utilization; Growth; Survival

\section{Introduction}

Malawi's fish production is dwindling and the development is not in tandem with the human population increase. In view of this, it is imperative to increase fish production to tally with the high market demand. To achieve this, there is a need to increase aquaculture production in Malawi through, among other important ways, fish feed supplementation. Thus, nutrition is critical in an effort to produce more fish. FAO [1] indicated that supplementation of fish diet increase yield over and above what would have been achieved without it.

A supplement is defined as a thing added to supply deficiencies. In aquaculture nutritional context, it will be tantamount to the supply of feed to meet one or more nutrient deficiencies of the system for the well-being of the stock (FAO) [1]. Supplementing the naturally available food in a culture system is the most simplistic functional interpretation of supplementary feeds. Supplementary feeding can affect feeding habits and food selection; the fish tend to select narrower range of food on supplementary feed regimes (FAO) [1]. According to Zaugg et al. [2] adding salt to the diet of fish has several advantages some of which are it increases appetite and also acts as humectants by reducing water activity.

Additives like sodium chloride are essentially ideal to enhance growth if incorporated in artificial feed as supplements. The use of salt (sodium chloride) is not a new advent. Salt is one of the essential mineral elements required by the animal and plant bodies for their normal functioning namely; making food taste better, regulating osmotic pressure of the body, form acid in mucous membrane of the stomach (activation of pepsin and enzymes of the salivary glands of the throat and keeping digestive processes normal). Elsewhere, research on salt supplementation has been conducted and yielded significant results. According to Nandeesha et al. [3] addition of salt to the diet of freshwater carp at $1.5 \%$ inclusion level resulted in better growth and is widely used in India. Therefore, knowing the optimal levels of different level of salt to be incorporated as a supplement in fish diet would play a vital role in enhancing feed intake and ultimately promote growth.

In freshwater-adapted fish, the passive outward flux of ions such as $\mathrm{Na}$ and $\mathrm{CI}$ from the fish to the external medium, via the gills, feaces and renal system must be overcome by active uptake of ion (e.g. $\mathrm{Na}^{+}$, $\mathrm{CL}-\mathrm{K}^{+}$and $\mathrm{Ca}^{2+}$ ) from the water and/or from the diet. Therefore, the diet constitutes an important source of salts that can satisfy the osmoregulatory requirements of fish kept in freshwater and thus spare energy used for osmoregulation leaving more energy available for somatic growth.

Addition of $2 \% \mathrm{NaCl}$ and $2 \%$ potassium chloride to practical diets has shown to have a positive effect on growth of red drum in freshwater and brackish (6 ppt) water but no positive effect were in full strength artificial seawater. The beneficial effect of dietary salt supplementation for red drum in dilute water appears to be due to provision of ions, which were relatively scarce in this hypotonic environment [4].

The beneficial effects of dietary salt supplementation on growth of freshwater and euryhaline fish have not been consistently observed; however, significant improvements in seawater have been noted [4]. A high-salt diet prior to transfer to sea water has also been found to reduce osmoregulatory stress and increase the survival rates in sea water of some African Tilapia (Oreochromis species).

Oreochromis shiranus being a freshwater is fish hyper osmotic to its surrounding medium, and encounter the physiological problem of solute loss and in order to compensate this, they resort to active uptake of salt ions from the medium. It is reasonable to expect that diet is an important source of salts that would satisfy the osmolegulatory requirement of Oreochromis shiranus and that supplemental salt

*Corresponding author: Mzengereza K, Department of Aquaculture and Fisheries Science, Lilongwe University of Agriculture and Natural Resources Bunda College, P.O. Box 219, Lilongwe, Malawi, Tel: +265 88899 8466; E-mail: kumbumzenge@yahoo.com

Received October 09, 2015; Accepted September 30, 2015; Published January 15,2016

Citation: Mzengereza K, Kang'ombe J (2015) Effect of Dietary Salt (Sodium Chloride) Supplementation on Growth, Survival and Feed Utilization of Oreochromis shiranus (Trewavas, 1941). J Aquac Res Development 6: 388. doi:10.4172/21559546.1000388

Copyright: (c) 2015 Mzengereza K, et al. This is an open-access article distributed under the terms of the Creative Commons Attribution License, which permits unrestricted use, distribution, and reproduction in any medium, provided the original author and source are credited. 
spares energy used in osmoregulation, thereby leaving more energy available for growth [5]. Study by Nandeesha et al. [3], affirms that the addition of salt to the diet of freshwater carp at $1.5 \%$ levels resulted in better growth and is widely used in India. This corresponds with an experiment conducted on juvenile red drum, where it was found out that addition of $2 \% \mathrm{NaCl}$ to the diet resulted in greater feed efficiency and greater weight gain [5].

Commercial aquaculture in Malawi is stagnating due to costly protein source especially fishmeal. Therefore, it is worthwhile finding ways of reducing protein intake without realizing significant decrease in growth. Salt act as a feed attractant can therefore help to minimize protein intake if incorporated into a diet. Freshwater fish, being hyper osmotic to the surrounding medium, encounter the physiological problem of solute loss and in order to compensate this, they resort to active uptake of salt ions from the medium. It is reasonable to expect that diet is an important source of salt that would satisfy the osmoregulatory requirement of the fish and that supplement salt spare energy used in osmoregulation, thereby leaving more energy available for growth. Until the recent survey, there had been no documentation that common salt was used as an additive to supplementary feed(s) (FAO) [1]. Therefore, results of this study are expected to provide information of salt as a fish diets supplement impact on growth performance; survival and feed convention ration Oreochromis shiranus.

\section{Material and Methods}

\section{Experimental site and fish}

The experiment was conducted inside the wet laboratory at Bunda fish farm using 100 litre tanks each stocked with 25 fish. It used water from the reservoir which is first pumped to the biofitration tank before it goes to the elevated storage tanks from where it is channeled through pipes to the hatchery and the laboratory. Seed (fingerings) were procured from earthen ponds at the farm with an average weight and total length of $12 \mathrm{~g}$ and $93 \mathrm{~mm}$ respectively. This was done to achieve uniform growth and minimize competition over space and food as recommended by Webster and Lim [6].

\section{Acclimatization}

Fingerings destined for the experiment were first acclimatized in concrete tanks for a fortnight.

\section{Diet preparation}

Soybean meal, maize bran and cassava flour were bought from areas in the vicinity of Bunda College, Lilongwe, Malawi. Dry fish, rice bran, unionized salt (sodium chloride) mineral and vitamin premixes were bought from Lilongwe market, Malawi. Soy bean was first roasted before grinding in line with Jauncey [7] who reported that raw bean contains a number of anti-nutritional factors, Soybean trypsin inhibitor which is destroyed by heating during processing. Samples of the ingredients were subjected to proximate analysis following the (AOAC) [8]. Mixed ingredients were used to formulate the diets as illustrated in Table 2. Finally, pellets of approximately 2-2.5 mm were produced using a meat mincer.

\section{Proximate analysis of feed ingredients}

The ingredients were assayed for in the aquaculture laboratory using proximate analysis using appropriate methods (AOAC) [8] before feed formulation (Tables 1 and 2).

\section{Experimental design}

The experiment was layed out in a Completely Randomized Design (CRD) using 100 litre tanks each stocked with 25 fingerings in triplicate totaling to 12 tanks. Fingerings were stocked at mean weight of $12 \mathrm{~g}$ to minimize competition over space and food as recommended by Webster and Lim [6]. Each of the diets was fed at $5 \%$ body weight twice a day $(8: 00-9.00$ am and 2:00 - 3:00 pm) for 90 days and the quantity of feed was adjusted after a fortnight. Mortality was monitored every day to calculate survival rate. Data on water quality parameters was recorded twice daily before feeding, temperature at (6:00 - 7:00 and 1:00 - 1:30) using a water checker.

\section{Sampling techniques and growth monitoring}

Sampling was done every fortnight. 15 fish from each tank were weighed $(\mathrm{g})$ using an electronic scale while measuring board was used to record standard length $(\mathrm{mm})$ Mortality was recorded every day. The following growth parameters were calculated using the following formulae:

$$
\begin{aligned}
& G_{R}=\frac{W G}{I W} ; \\
& S G R=\frac{\log _{W_{2}}}{T_{2}}-\frac{\log _{w_{1}}}{T_{1}} \\
& F C R=\frac{F I}{W G} ; \\
& \text { Survival }=\frac{N_{H-} N_{S}}{N_{S}}
\end{aligned}
$$

Data analysis was done using SPSS-Statistical Package for Social Scientists (16.0 versions). One-way analysis of variance (ANOVA) was

\begin{tabular}{|l|l|l|l|l|}
\hline Proximate Component & Maize bran & Fish meal & Rice bran & Soy bean \\
\hline Dry Matter \% & $91.3^{\mathrm{a}}$ & $91.9^{\mathrm{a}}$ & $91.4^{\mathrm{a}}$ & $92.09^{\mathrm{b}}$ \\
\hline Crude Protein \% & $10.2^{\mathrm{a}}$ & $62.14^{\mathrm{b}}$ & $9.53^{\mathrm{b}}$ & $42.1^{\mathrm{d}}$ \\
\hline Ash \% & $3.41^{\mathrm{a}}$ & $11.64^{\mathrm{b}}$ & $5.48^{\mathrm{c}}$ & $4.13^{\mathrm{d}}$ \\
\hline Fat \% & $0.17^{\mathrm{a}}$ & $13.87^{\mathrm{b}}$ & $1.65^{\mathrm{c}}$ & $18.90^{\mathrm{d}}$ \\
\hline
\end{tabular}

Means in the row with the same superscript letter are not significantly differen $(\mathrm{P}>0.05)$.

Table 1: Proximate analysis of feed ingredients used in feed formulation.

\begin{tabular}{|l|l|l|l|l|}
\hline Ingredient & $\begin{array}{l}\text { Diet 1 } \\
(0 \% \text { salt })\end{array}$ & $\begin{array}{l}\text { Diet 2 } \\
(1 \% \text { salt })\end{array}$ & $\begin{array}{l}\text { Diet 3 } \\
(1.5 \% \text { salt })\end{array}$ & $\begin{array}{l}\text { Diet 4 } \\
(2 \% \text { salt })\end{array}$ \\
\hline Fish meal & 21.90 & 21.65 & 25.52 & 21.40 \\
\hline Soybean meal & 21.90 & 21.65 & 25.52 & 21.40 \\
\hline Maize bran & 25.60 & 25.35 & 25.23 & 25.10 \\
\hline Rice bran & 25.60 & 25.35 & 25.23 & 25.10 \\
\hline Cassava flour & 2.0 & 2.0 & 2.0 & 2.0 \\
\hline Salt & 0 & 1. & 1.5 & 2.0 \\
\hline Vitamins $1^{*}$ & 1.5 & 1.5 & 1.5 & 1.5 \\
\hline Minerals 2* & 1.5 & 1.5 & 1.5 & 1.5 \\
\hline Total & 100 & 100 & 100 & 100 \\
\hline
\end{tabular}

$1^{*}$.Vitamin premixes (as active matter g/100): A, 2000, $000 \mathrm{UI}$; D3 245, $000 \mathrm{UI}$; E 1, 000 UI; C, 500g; B12, 3 mg; d-Pantothenic, (B6), 100 mg; pyridoxine, $100 \mathrm{mg}$

$2^{*}$. Mineral premixes (as active matter $\mathrm{g} / 100$ ): Calcium hydrogen orthophosphate, 10.29; Magnesium sulphate, 50.00; Sodium chloride, 30.00; Potassium chloride, 5.00; Zinc sulphate, 2.75; Manganese sulphate, 1.27; Copper sulphate, 0.39; Cobalt sulphate, 0.24; Chromic chloride, 0.064. Premixes contained also $1.06 \mathrm{~g}$ Potassium and $21.2 \mathrm{~g}$, Sodium salts.

Table 2: Composition of the experimental diets $(\mathrm{Kg})$ fed to Oreochromis shiranus 
used to test significant differences among treatment means at $0.05 \%$ alpha level. Least Significant difference (LSD) test was employed to separate significantly different means.

\section{Results}

\section{Fish growth}

There was no significant difference $(\mathrm{P}>0.05)$ among treatments in the first 2 weeks in terms of weight gain. From week 2 to week 10, growth was significantly different $(\mathrm{P}<0.05)$ among treatments. Treatment 3 (1.5\% salt level) and treatment $2(1 \%$ salt level) had higher mean weight gains recording $18.69 \mathrm{~g}$ and 17.19 respectively while treatment 4 and treatment 1 registered $15.93 \mathrm{~g}$ and16.32 mean weights at harvest (Figure 1 and Tables 3-5).

\section{Survival of fish}

Survival was not significantly different $(\mathrm{P}>0.05)$ among treatments (Table 4). Survival rate was higher in treatments 1 and 4 while treatment 3 had the lowest survival.

\section{Discussion}

Results show that higher fish growth was observed at $1 \%$ and $1.5 \%$ salt inclusion level (Table 4). Thus, consistent to a large dimension with other researchers in that significant growth can be observed when fish are fed on salty diet than salt free diet. The addition of salt to the diet of freshwater carp at a level of $1.5 \%$ resulted in significantly better growth and is in widespread use in India [3]. The final weight gain of Rohu, Labeo rotiha fed $0.5 \%$ and $1 \% \mathrm{NaCI}$-incorporated diets were significantly $(\mathrm{P}<0.005)$ higher than that of the control $(0 \% \mathrm{NaCI})[9]$. Freshwater fish, being osmotic to the surrounding medium, encounter the physiological problem of solute loss and in order to compensate this, they resort to active uptake of salt ions from the medium [5]. Therefore, it is reasonable to speculate that dietary salt satisfied the osmolegulatory requirement of Oreochromis shiranus as it is a freshwater fish and that supplemental salt spared energy used in osmoregulation, thereby leaving more energy for somatic growth. Smith et al. [10] reported that the dietary sodium intake of salmonids kept in fresh water increased by eightfold from winter to summer. This corresponds to the increase in feeding and shows that almost all the sodium required can be derived from dietary salt. This can therefore be used as a source of salts for fish kept in freshwater, providing ions which the fish cannot obtain from the hypotonic environment.

In addition, Asian sea bass Lates calcirifer reared in freshwater recirculating fed $1 \% \mathrm{NaCI}$ diet exhibited a better feed conversion ratio and a higher (yet not significant) growth, not only that, but also enhanced the activity of brush body enzymes e.g. leucine amino peptidase and were pronounced in pyloric caeca [11]. The better enzymatic activity can be explained by the absorption mechanism of end products -glucose and amino acids. Since the glucose and most of amino acids is dependent on the $\mathrm{Na}+\mathrm{K}+$ ATPse pump [12], a higher concentration of $\mathrm{Na}+$ in the lumen might lead to a better absorption of carbohydrates and amino acids. Since the activity might be inhibited by its end products (amino acids and carbohydrates) [13], reduction of the end products concentration can lead to better enzyme activity in the lumen of fish fed feed enhanced with $\mathrm{NaCl}$. Therefore, the previous work corroborates with this study in that Oreochromis shiranus had a better enzyme activity owing to dietary $\mathrm{NaCl}$, thus registering a better growth $1 \%$ and $1.5 \%$ inclusion level.

Salt appears to affect growth rate inversely when the level of supplementation interferers with the balance of other essential dietary components. Feeding supplementary $\mathrm{NaCI}$ in freshwater has strongly stimulated gill $\mathrm{Na}+-\mathrm{K}+-$ ATPse activity, which has been found to be accompanied by an increase in the number of chloride cells. This is ascribed to the need for increased gill $\mathrm{NaCI}$ extrusion capacity because the salty diet imposed a salt load that exceeded the normal capacity for diffusion loss across the gills and the excretion through urine [14] The decrease in weight gain and SGR of Oreochromis shiranus in the present study could be at $2 \%$ could be because of excess salt level that hindered other metabolic processes responsible for growth.

However, there was slow fish growth in the first two weeks among all treatments but increased later. This might be because the fish were still in the process of being accustomed to the new feed and the environment of the experimental unit. According to Likongwe [15], and Lovell [16], there is a specific period of rapid growth in the growth curve of fish.

The experiment also indicates that fish fed on $1 \% \mathrm{NaCI}$ and $1.5 \%$ $\mathrm{NaCI}$ levels had a better utilization of feed as evidenced in the lower Feed Conversion Ratio of 1.51 and 1.47 respectively (Table 4). This is an indication that feed was appropriately utilized and hence a superior growth rate. The results agrees favorably with Gangadhara et al. [9] reported that $0.5 \% \mathrm{NaCI}$ and $1 \% \mathrm{NaCI}$ produced better FCRs at 1.56 and 1.44 respectively and subsequently higher growth rate. Fish feeds constitute one of the most expensive components in rearing of fish, and high protein levels required for these fish are also a major source of nitrogenous products harmful to fish in closed systems. Therefore, the fact that the addition salt to the feed resulted in a better FCR is of great importance as this is an indication of good feed conversion into fresh. $2 \% \mathrm{NaCI}$ had the highest FCR clearly showing that feed utilization was poor. Low digestibility and faster evaluation of food have been associated with high levels of $\mathrm{NaCI}$ in diets [17]. This in turn could affect assimilation and conversion efficiency. It is, therefore, reasonable to suggest that $2 \%$ salt level led to excessive salt loading and adversely affected feed intake, digestion and/or absorption, because of

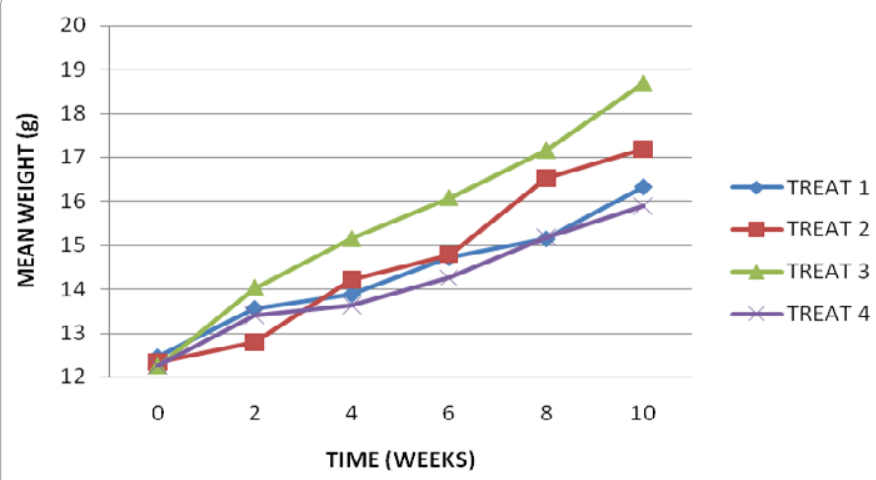

Figure 1: Growth trend in weight $(\mathrm{g})$ of Oreochromis shiranus fed on different salt (sodium chloride) levels in the diets.

\begin{tabular}{|l|l|l|l|l|}
\hline $\begin{array}{l}\text { Proximate } \\
\text { Component }\end{array}$ & $\begin{array}{l}\text { Diet 1 } \\
\text { (0\% salt) }\end{array}$ & $\begin{array}{l}\text { Diet 2 } \\
\mathbf{( 1 . 0 \% ~ s a l t ) ~}\end{array}$ & $\begin{array}{l}\text { Diet 3 } \\
\mathbf{( 1 . 5 \% ~ s a l t ) ~}\end{array}$ & $\begin{array}{l}\text { Diet 4 } \\
\mathbf{( 2 . 0 \% ~ s a l t ) ~}\end{array}$ \\
\hline Dry mater & $92.28 \pm 0.27^{\mathrm{a}}$ & $92.22 \pm 0.12^{\mathrm{a}}$ & $92.44 \pm 0.27^{\mathrm{a}}$ & $90.48 \pm 0.6^{\mathrm{b}}$ \\
\hline Fat $(\%)$ & $14.21 \pm 0.05^{\mathrm{a}}$ & $16.01 \pm 0.0^{\mathrm{b}}$ & $19.87 \pm 0.06^{\mathrm{c}}$ & $15.14 \pm 0.04^{\mathrm{a}}$ \\
\hline C P (\%) & $30.70 \pm 0.02^{\mathrm{a}}$ & $30.63 \pm 0.12^{\mathrm{a}}$ & $30.48 \pm 0.05^{\mathrm{a}}$ & $30.41 \pm 0.02^{\mathrm{a}}$ \\
\hline Ash & $14 \pm 0.04^{\mathrm{a}}$ & $12.42 \pm 0.2^{\mathrm{b}}$ & $10.65 \pm 0.03^{\mathrm{c}}$ & $13.70 \pm 0.23^{\mathrm{a}}$ \\
\hline Energy(kJ/g) & $21.04 \pm 0.2^{\mathrm{a}}$ & $21.35 \pm 0.10^{\mathrm{a}}$ & $21.56 \pm 0.23^{\mathrm{a}}$ & $20.21 \pm 0.15^{\mathrm{b}}$ \\
\hline
\end{tabular}

Means in the row with the same superscript letter are not significantly different $(P>0.05)$.

Table 3: Proximate composition of experimental diets (Mean \pm SE). 
Citation: Mzengereza K, Kang'ombe J (2015) Effect of Dietary Salt (Sodium Chloride) Supplementation on Growth, Survival and Feed Utilization of Oreochromis shiranus (Trewavas, 1941). J Aquac Res Development 6: 388. doi:10.4172/2155-9546.1000388

the changed gastric/intestinal environment and may even have had pathological effects on Oreochromis shiranus in this experiment. That is probably the reason for a depressed weight gain and SGR.

Water quality parameters were within limit throughout the experiment (Table 5). Temperature ranged from $20^{\circ} \mathrm{C}$ to $24^{\circ} \mathrm{C}$ which is within the recommended levels. Claude reported that the optimal temperature range for warm water fish is $20^{\circ} \mathrm{C}$ to $28^{\circ} \mathrm{C}$ but these are typically encountered in the natural regimes [18]. Dissolved oxygen ranged from 7.02 to $8.71 \mathrm{mg} / \mathrm{L}$ and this was within tolerable limit. Claude reported that dissolved oxygen of above $5 \mathrm{mg} / \mathrm{L}$ augurs well for the survival of fish [18]. In the present study, $\mathrm{pH}$ levels ranged from 7.78 to 8.21 and are considered desirable and could in no way negatively affect growth, survival and feed utilization of Oreochromis shiranus. According to FAO [19], the optimal PH levels are 4 to 10 of which below or above become detrimental to fish survival. $\mathrm{NH}_{3}$ and salinity were also not significantly different $(\mathrm{P}>0.05)$ among treatments. However, $\mathrm{NH}_{3}$ were sometimes slightly higher with a maximum of 0.38 $\mathrm{mg} / \mathrm{L}$ (Table 4) but this did not have adverse effects on the survival of Oreochromis shiranus. According to Lovell, Tilapia can tolerate $\mathrm{NH}_{3}$ levels up to $2.4 \mathrm{mg} / \mathrm{L}$ [16]. Survival was higher in diet1, $0 \% \mathrm{NaCI}$ level $(97.7 \%)$ and lowest in diet $2,1 \% \mathrm{NaCI}(94.8 \%)$. This meant that survival did not depend on sodium chloride level.

\section{Conclusion}

Different salt $(\mathrm{NaCI})$ levels in a diet of Oreochromis shiranus exhibit different growth responses. Salt level of 1.5\% (treatment 3) is optimum for incorporation in diets of Oreochromis shiranus. 1\% inclusion level plays second fiddle. Feed utilization was better in both $1 \%$ and $1.5 \%$ salt inclusion levels with 1.54 and 1.44 FCRs respectively. At 2\% SGR, FCR and weight gain diminished, thus an increase in salt level beyond a certain (optimum) level make the feed less appropriate for consumption and affect growth negatively.

\section{Recommendation}

The intensive rearing of fish in closed systems is costly due to high cost of feed like fish meal and calls for methods that will enhance food utilization and growth while generating economic returns. Utilizing a diet enhanced with $1 \%$ to $1.5 \%$ salt has an advantage on Tilapia species (Oreochromis shiranus), as observed from the results of the present study. It can lead to better feed utilization under intensive production conditions and can reduce the cost of feed since there is dilution of expensive component with a cheap mineral. This simple method can be used by small-scale fish farmers and does not require special means. Optimum salt content must be taken into account to prevent growth reduction owing to excess salt incorporation.

\begin{tabular}{|l|l|l|l|l|}
\hline PARAMETER & $\begin{array}{l}\text { Treatment 1 } \\
\text { (0\% salt) }\end{array}$ & $\begin{array}{l}\text { Treatment 2 } \\
(\mathbf{1 . 0 \%} \text { salt) }\end{array}$ & $\begin{array}{l}\text { Treatment 3 } \\
\mathbf{( 1 . 5 \% ~ s a l t ) ~}\end{array}$ & $\begin{array}{l}\text { Treatment 4 } \\
\text { (2.0\% salt) }\end{array}$ \\
\hline Initial Weight(g) & $12.46 \pm 0.19^{\mathrm{a}}$ & $12.34 \pm 0.09^{\mathrm{a}}$ & $12.24 \pm 0.24^{\mathrm{a}}$ & $12.26 \pm 0.11^{\mathrm{a}}$ \\
\hline Final Weight(g) & $16.32 \pm 0.99^{\mathrm{a}}$ & $17.19 \pm 0.19^{\mathrm{b}}$ & $18.69 \pm 0.22^{\mathrm{c}}$ & $15.93 \pm 0.19^{\mathrm{a}}$ \\
\hline Weight gain (g) & $3.86 \pm 0.86^{\mathrm{a}}$ & $4.84 \pm 0.41^{\mathrm{b}}$ & $6.45 \pm 0.38^{\mathrm{c}}$ & $3.67 \pm 0.15^{\mathrm{a}}$ \\
\hline Weight gain/day(g) & $0.05 \pm 0.01^{\mathrm{a}}$ & $0.06 \pm 0.01^{\mathrm{b}}$ & $0.07 \pm 0.003^{\mathrm{c}}$ & $0.05 \pm 0.003^{\mathrm{a}}$ \\
\hline SGR (\%) & $0.33 \pm 0.06^{\mathrm{a}}$ & $0.41 \pm 0.04^{\mathrm{b}}$ & $0.52 \pm 0.03^{\mathrm{c}}$ & $0.32 \pm 0.01^{\mathrm{a}}$ \\
\hline FCR & $1.77 \pm 0.06^{\mathrm{a}}$ & $1.51 \pm 0.06^{\mathrm{b}}$ & $1.44 \pm 0.08^{\mathrm{c}}$ & $1.87 \pm 0.09^{\mathrm{a}}$ \\
\hline Survival (\%) & $97.7 \pm 0.5$ & $94.8 \pm 0.8$ & $96.2 \pm 0.9$ & $95.5 \pm 0.7$ \\
\hline
\end{tabular}

Means in the row sharing the same superscript letter are not significantly different $(P>0.05)$.

Table 4: Mean initial weights, daily weight gain, Feed conversion ratio (FCR), Specific growth rate (SGR \%/day) of Oreochromis shiranus raised on different salt $(\mathrm{NaCl})$ diets in $100 \mathrm{~L}$ tanks: (Mean $\pm \mathrm{SE})$.

\begin{tabular}{|l|l|l|l|l|}
\hline Parameter & $\begin{array}{l}\text { Treatment 1 } \\
\text { (0\% salt) }\end{array}$ & $\begin{array}{l}\text { Treatment 2 } \\
\mathbf{( 1 . 0 \% ~ s a l t ) ~}\end{array}$ & $\begin{array}{l}\text { Treatment 3 } \\
\text { (1.5\% salt) }\end{array}$ & $\begin{array}{l}\text { Treatment 4 } \\
\text { (2.0\% salt) }\end{array}$ \\
\hline Temperature morning & $20.53 \pm 0.13^{\mathrm{a}}$ & $20.57 \pm 0.12^{\mathrm{a}}$ & $21.53 \pm 0.13^{\mathrm{a}}$ & $20.08 \pm 0.13^{\mathrm{a}}$ \\
\hline afternoon & $22.57 \pm 0.11 \mathrm{a}$ & $23.27 \pm 0.10^{\mathrm{a}}$ & $23.31 \pm 0.10^{\mathrm{a}}$ & $23.24 \pm 0.10^{\mathrm{a}}$ \\
\hline $\mathrm{PH}$ morning & $8.10 \pm 0.03^{\mathrm{a}}$ & $7.9 \pm 0.04^{\mathrm{a}}$ & $8.13 \pm 0.04^{\mathrm{a}}$ & $8.27 \pm 0.03^{\mathrm{a}}$ \\
afternoon & $7.96 \pm 0.05^{\mathrm{a}}$ & $8.09 \pm 0.06^{\mathrm{a}}$ & $8.09 \pm 0.06^{\mathrm{a}}$ & $8.17 \pm 0.06^{\mathrm{a}}$ \\
\hline Ammonia $\left(\mathrm{NH}_{3}\right)$ & $0.389 \pm 0.02^{\mathrm{a}}$ & $0.227 \pm 0.03^{\mathrm{b}}$ & $0.327 \pm 0.04^{\mathrm{a}}$ & $0.343 \pm 0.04^{\mathrm{a}}$ \\
\hline Dissolved oxygen (DO) & $7.87 \pm 0.07^{\mathrm{a}}$ & $8.06 \pm 0.08^{\mathrm{b}}$ & $8.23 \pm 0.08^{\mathrm{b}}$ & $7.02 \pm 0.07^{\mathrm{a}}$ \\
\hline
\end{tabular}

Means in the row sharing the same superscript letter are not significantly different $(P>0.05)$.

Table 5: Water quality parameters observed throughout the experimental period.

\section{Acknowledgement}

The authors wish to thank the crew at Lilongwe University of Agriculture and Natural Resources, department of aquaculture and fisheries science laboratory for technical assistance. Special mention is Mr Elton Nyali, chief technician for his tireless effort.

\section{References}

1. FAO (1995) Farm-made aqua feeds, Viale delle Terme di Cracalla, 00100 Rome, Italy.

2. Zaugg WS, RoD D, Prencice EF, Gores KX, Waknizt FW (1983) Increased Seawater survival and contribution to the fishery of Chinook salmon (Oncorhynchus Tshawytscha) by supplemental dietary salt. Aquaculture 32 183-188.

3. Nandeesha MC, Gangadhar B, Keshavanath P, Varghese TJ (2000) Effect of dietary salt supplementation on growth, biochemical composition and digestive enzyme activity of young Cyprinus carpio (Linn) Cirrhinus mrigala (Ham). Journal of aquaculture in the tropics 15: 135-144.

4. Lim C, David JS (1994) Nutrition and Utilization Technology in Aquaculture AOUS press, Chapman and Hall, Illinois, USA.

5. Gatlin DM, Mackenzie DS, Craig SR, Neill WAH (2000) Effects of dietary sodium chloride on red drum juveniles in waters of various salinities. Progressive fish Culturist.

6. Webster CD, Lim CE (2002) Nutrient requirement and feeding of finfish for Aquaculture, CABI publishing, Wallington, U.K.

7. Jauncey K, Ross B (1998) A guilde to Tilapia feeds and feeding. University of Stirling.

8. AOAC (2003) Official Methods of Analysis.(15edn), Association of Official Analytical Chemists. Washington, DC, USA.

9. Gangadhara B, Keshvaanar P, Varghese TJ (2004) Growth performance, Feed Utilization and Body Composition of Rohu (Lebo rotiha) fed salt incorporated diets. Canadian Journal of Fisheries Science 23: 98-99.

10. Smith AA, Craig SR, Neil WAH (1989) Effect of supplemental dietary sodium chloride on growth rate of Tilapia, Oreochromis Shiranus. Canadian Journal of Fisheries and Aquatic science 11: 719-726.

11. Harpaz M (2005) Marine fish Biology. Elsevier Company, Porstmouth, UK

12. Klein S, Cohn SM, Alpers DH (1998) The alimentary canal in nutrition. (9thedn), William and Wilkins, Baltimore, MD.

13. De la Fuente JL, Rumbero A, Martin JF, Liras P (1997) Delta-1-piperideine-6carboxylate dehydrogenase, a new enzyme that forms alpha-aminoadipase in stretomyces clavuligerus and other cephamycin C-producing actinomycetes. Journal of Biochemistry 327: 59-64

14. Staurnaes M, Asgurd T, Griffiths D, Husbay J, Einarsdottir I, et al. (1990) Effects of dietary $\mathrm{NaCl}$ supplementation on Smoltification and sea water tolerance in Atlantic salmon reared to smolt development at time release. Aquaculture 118 : 327-337.

15. Likongwe JS (1998) Effect of varying dietary energy level on growth and feed conversion of juvenile Tilapia , Oreochromis niloticus at salinity level. Proceeding of the first regional workshop in Aquaculture, Bunda college of Agriculture, Lilongwe, Malawi.

16. Lovell T (1989) Nutrition and Feeding of Fish. Van Nostrad Reinhold, New York 
Citation: Mzengereza K, Kang'ombe J (2015) Effect of Dietary Salt (Sodium Chloride) Supplementation on Growth, Survival and Feed Utilization of Oreochromis shiranus (Trewavas, 1941). J Aquac Res Development 6: 388. doi:10.4172/2155-9546.1000388

Page 5 of 5

17. Salman NA, Eddy FB (1987) Effect Of different sodium chloride on growth food intake and conversion efficiency in rainball trout (salmo gaidneri Richardson) Aquaculture 70: 131-144.
18. Claude EB (1990) Water quality in pond for Aquaculture, Birmingham publishing company. Birmigham, United Kingdom.

19. FAO (1988) Inland fish enhancement, Toowimba, Queensland, Australia. 